\title{
Szybkość, sprawność i efektywność postępowania cywilnego - zagadnienia podstawowe
}

\section{Wstęp}

W/spółczesne podejście do wymiaru sprawiedliwości w sprawach cywilnych koncentruje się na postrzeganiu go w kategoriach usługi publicznej o szczególnym charakterze. Dostrzegają to również organy administracji publicznej odpowiedzialne za aspekty organizacyjne i finansowe sądownictwa powszechnego. W jednym z dokumentów rządowych z 2010 r. pojawiło się stwierdzenie, iż zdolność instytucjonalna organów państwa, jest - w warunkach nowoczesnego społeczeństwa obywatelskiego - podstawowym wyznacznikiem autorytetu społecznego każdej z władz publicznych, w tym władzy sądowniczej. Autorytet wymiaru sprawiedliwości nie może nadal wynikać wyłącznie z konstytucyjnej pozycji trzeciej władzy oraz przekonania, że jej przedstawiciele realizują misję publiczną, której efektów nie sposób wartościować. W dzisiejszej dobie podstawą autorytetu organów władzy publicznej - w tym wymiaru sprawiedliwości jest jakość i efektywność działania. Pojęcia te są ze sobą ściśle związane, gdyż efektywność pracy nowoczesnych organizacji uzyskuje się poprzez właściwe zarządzanie jakością. Należy zarazem stale porównywać ze sobą działanie podobnych organizacji z danego obszaru aktywności państwa ${ }^{1}$. W celu obiektywizacji

\footnotetext{
* Dr hab. Kinga Flaga-Gieruszyńska prof. US - Katedra Postępowania Cywilnego, Wydział Prawa i Administracji Uniwersytet Szczeciński; e-mail: kingaflaga@gmail.com.

${ }^{1}$ Skuteczny wymiar sprawiedliwości - działania Ministerstwa Sprawiedliwości na 500 dni, Warszawa 2010 r., https://ms.gov.pl/Data/Files/_public/aktual/skuteczny_wymiar_sprawiedliwosci_dzialania_ministerstwa_sprawiedliwosci_na_500_dni.pdf, s. 4.
} 
tych porównań należy ustalić te mierniki, które mają rzeczywiste znaczenie dla podnoszenia jakości wymiaru sprawiedliwości z perspektywy podmiotów poszukujących skutecznej ochrony prawnej. $\mathrm{W}$ tym wypadku z pewnością istotne będą kwestie związane z czasem postępowania (szybkość), sposobem zorganizowania postępowania (sprawność) oraz z trafnością rozstrzygnięć w korelacji z kosztami postępowania (efektywność), co uzasadnia pogłębioną analizę tych zagadnień, przede wszystkim z perspektywy postanowień Kodeksu postępowania cywilnego ${ }^{2} \mathrm{i}$ innych regulacji rangi ustawowej oraz aktów prawa międzynarodowego, z uwzględnieniem ich interpretacji przede wszystkim na gruncie współczesnego orzecznictwa. Zderzenie modeli teoretycznych działania sądów powszechnych wynikających przede wszystkich z konstrukcji ustawy procesowej oraz przepisów ustrojowych z praktyką stosowania prawa pozwala zweryfikować ich znaczenie praktyczne dla kształtowania standardów efektywnej ochrony prawnej w sprawach cywilnych.

\section{Szybkość postępowania cywilnego}

Z uwagi na brak definicji legalnej terminu „szybkość” w odniesieniu do postępowań sądowych, należy się odnieść do definicji funkcjonujących w języku ogólnym. „Szybkość” w podstawowym znaczeniu to „cecha tego, co przebiega w większym tempie, z większą częstotliwością, krócej niż zwykle”3, „tempo, w jakim coś się odbywa"4. Dla szybkości jako postulatu odnoszącego się do postępowania cywilnego fundamentalne znaczenie mają postanowienia art. 6 k.p.c., zgodnie z którym sąd powinien przeciwdziałać przewlekaniu postępowania i dążyć do tego, aby rozstrzygnięcie nastąpiło na pierwszym posiedzeniu, jeżeli jest to możliwe bez szkody dla wyjaśnienia sprawy. Natomiast strony i uczestnicy postępowania obowiązani są przytaczać wszystkie okoliczności faktyczne i dowody bez zwłoki, aby postępowanie mogło być przeprowadzone sprawnie i szybko. Tym samym ustawodawca rozdziela wyraźnie cechę szybkości i sprawności, a więc ocenę postępowania w aspekcie czasu jego przeprowadzania oraz w kontekście jakości postępowania jako zorganizowanego ciągu czynności nastawionego na określony cel (trafne rozstrzygnięcie sporu względnie jego rozwiązanie poprzez ugodę stron). Dlatego też obie te cechy należy omówić odrębnie.

Jednak szybkość postępowania nie jest wartością o bezwzględnym charakterze, ponieważ ma ona znaczenie tylko przy jednoczesnym zapewnieniu osiągnięcia zasadniczego celu postępowania. Wzgląd na szybkość postępowania

${ }^{2}$ Ustawa z 17 listopada 1964 r. - Kodeks postępowania cywilnego (t. jedn. Dz.U. z 2016 r. poz. $1822 \mathrm{ze} \mathrm{zm}$.

${ }^{3}$ http://sjp.pwn.pl/szukaj/szybko\%C5\%9B\%C4\%87.html, 20.04 .2017 r.

${ }^{4}$ http://www.wsjp.pl/index.php?id_hasla=38413\&id_znaczenia=4208047\&l=22\&ind=0, 20.04.2017 r. 
- skądinąd stanowiącą podstawową wartość, która powinna być konsekwentnie realizowana w każdym procesie - nie może przesłaniać prawa strony do obrony i prowadzić do pozbawienia lub jego ograniczenia ${ }^{5}$. Szybkość rozpoznawania spraw (art. 6 k.p.c.) nie może odbywać się kosztem niewyjaśnienia istotnych dla ich rozstrzygnięcia okoliczności (art. $3 \$ 2$ k.p.c.) ${ }^{6}$. Warto zauważyć, że w zakresie szybkości postępowania (a wydaje się również, że w odniesieniu do jego sprawności) zasadnicze znaczenie mają nie tylko działania sądu, ale również czynności stron i innych uczestników postępowania, które w sumie wyznaczają jego tempo. W swoim orzecznictwie Sąd Najwyższy zwraca uwagę sądów na konieczność szybkiego i zgodnego z wymogami obowiązujących przepisów prawa rozpoznania spraw, należących do ich właściwości, co nie upoważnia jednak sądów do stosowania - w imię szybkości postępowania - uproszczeń pozostających w sprzeczności ze wspomnianymi przepisami i mogącymi wywrzeć niekorzystny wpływ na rozstrzygnięcie sprawy w sposób zgodny z prawdą? Jednak - jak już zasygnalizowano - nie oznacza to jednak obciążenia składu orzekającego wyłącznym ciężarem przyspieszania postępowania bez szkody dla jakości rozstrzygnięcia, z wyłączeniem odpowiedzialności stron postępowania. W tym przypadku mamy jednoznacznie do czynienia ze swoistym współdziałaniem sądu i stron oraz innych uczestników postępowania w celu jego przyspieszenia.

W pierwszej kolejności warto spojrzeć na to zagadnienie z perspektywy obowiązków i ograniczeń odnoszących się do aktywności sądu w toku postępowania dowodowego. W szczególności sąd z pewnością nie może dokonywać czynności, którymi wyręcza stronę wykazującą się biernością w toku postępowania. Wynika to również z postanowień art. 3 k.p.c., zgodnie z którym strony i uczestnicy postępowania obowiązani są dokonywać czynności procesowych zgodnie z dobrymi obyczajami, dawać wyjaśnienia co do okoliczności sprawy zgodnie z prawdą i bez zatajania czegokolwiek oraz przedstawiać dowody. Przejawem działania sprzecznego z dobrymi obyczajami jest podejmowanie przez stronę czynności, przewidzianych wprawdzie przez ustawę i formalnie dopuszczalnych, które jednak - w okolicznościach konkretnej sprawy - są wykorzystywane niezgodnie z funkcją przepisu, w sposób nieodpowiadający rzeczywistemu celowi przyznanego uprawnienia i naruszający prawo drugiej strony do uzyskania efektywnej ochrony prawnej. Zakaz nadużywania praw procesowych jest wywodzony z zasady uczciwego i rzetelnego procesu, obowiązku uczciwego, zgodnego z dobrymi obyczajami działania uczestników postępowania oraz z celu (istoty) postępowania cywilnego. Jednocześnie umożliwia on przeciwdziałanie wyko-

\footnotetext{
${ }^{5}$ Wyrok SN z dnia 16 lipca 2009 r., I CSK 30/09, Legalis.

${ }^{6}$ Wyrok SN z dnia 22 września 1994 r., III CRN 30/94, Legalis.

7 Wyrok SN z dnia 19 maja 1976 r., IV PRN 9/76, Legalis.
} 
rzystywaniu określonego uprawnienia procesowego w sposób sprzeczny z funkcją przepisów oraz może mieć znaczenie dla wykładni i stosowania przepisów postępowania przez sąd i przekładać się na konkretne decyzje procesowe ${ }^{8}$. W kontekście szybkości postępowania można przykładowo wskazać, że wielokrotne składanie przez stronę wniosków o wyłączenie sędziego, opartych na tych samych ogólnikowych zarzutach, niedających się zweryfikować i w sposób oczywisty godzących w powagę sądu, jest nadużyciem praw procesowych ${ }^{9}$. W tym względzie istotne znaczenie ma art. 103 k.p.c., mający przede wszystkim charakter represyjny w razie niewłaściwego zachowania stron postępowania. Niezależnie od wyniku sprawy sąd może włożyć na stronę lub interwenienta obowiązek zwrotu kosztów, wywołanych ich niesumiennym lub oczywiście niewłaściwym postępowaniem. Dotyczy to m.in. kosztów powstałych wskutek opóźnionego powołania dowodów przez stronę postępowania działającą na jego przewlekłość.

Tym samym wydaje się, że co prawda przepis art. 6 k.p.c. ma w pierwszym rzędzie przeciwdziałać destrukcji procesowej ze strony uczestników postępowania, jednak oczywiste jest również i to, że do jego naruszenia dochodzi, gdy to sąd swoja bezczynnością doprowadza do niczym nieuzasadnionej zwłoki w rozpoznaniu konkretnych spraw ${ }^{10}$. Odnosi się to do zwłaszcza do sytuacji, w których ustawodawca w postanowieniach szczegółowych ustawy procesowej wprowadza rozwiązania dające przewodniczącemu względnie sądowi instrumentarium pozwalające na przyspieszenie toku postępowania, z poszanowaniem reguł jego rzetelności, a organy uprawnione nie wykorzystują swoich możliwości w należyty i wystarczająco efektywny sposób.

W myśl art. $207 \$ 6$ k.p.c. sąd pomija spóźnione twierdzenia i dowody, chyba że strona uprawdopodobni, że nie zgłosiła ich w pozwie, odpowiedzi na pozew lub dalszym piśmie przygotowawczym bez swojej winy lub że uwzględnienie spóźnionych twierdzeń i dowodów nie spowoduje zwłoki w rozpoznaniu sprawy albo że występują inne wyjątkowe okoliczności. $Z$ tego przepisu, będącego ucieleśnieniem i zarazem skutkiem wyrażonego w art. $6 \$ 2$ k.p.c. postulatu szybkości postępowania, wynika, że jeśli wskazane w nim wyjątki nie występują, to obowiązkiem sądu jest pominięcie spóźnionych twierdzeń i dowodów, na co wprost wskazuje użycie przez ustawodawcę zwrotu „sąd pomija”, nie zaś „może pominąć” lub innego pozwalającego na pozostawienie kwestii dopuszczenia spóźnionych dowodów swobodnej ocenie sądu ${ }^{11}$. Obowiązek wskazania dowodów, potrzebnych do rozstrzygnięcia sprawy, obciąża strony. W konsekwencji sąd jest wyposażony jedynie w uprawnienie (a nie obowiązek) dopuszczenia

\footnotetext{
${ }^{8}$ Postanowienie SN z dnia 16 czerwca 2016 r., V CSK 649/15, Legalis.

${ }^{9}$ Ibidem.

${ }^{10}$ Wyrok SN z dnia 13 września 2011 r., SNO 33/11, Legalis.

${ }^{11}$ Wyrok SA w Białymstoku z dnia 4 sierpnia 2016 r., I ACa 235/16, Legalis.
} 
dalszych jeszcze, nie wskazanych przez żadną ze stron, dowodów, ale kieruje się w tym własną oceną, czy zebrany w sprawie materiał jest dostateczny do jej rozstrzygnięcia. Możliwość dopuszczenia przez sąd dowodu nie wskazanego przez strony nie oznacza, że sąd obowiązany jest zastąpić własnym działaniem bezczynność strony ${ }^{12}$. Wynika to również z art. 232 k.p.c., który stanowi, że strony są obowiązane wskazywać dowody dla stwierdzenia faktów, z których wywodzą skutki prawne. Natomiast zawarte w drugim zdaniu tego przepisu formułowanie „sąd może dopuścić dowód niewskazany przez stronę” należy rozumieć jako upoważnienie, a nie źródło obowiązku sądu w zakresie poszukiwania dowodów i zastępowania tym sposobem niezbędnej inicjatywy stron ${ }^{13}$. W tym przypadku szybkość postępowania należy postrzegać jedynie jako postulat, który nie może przełamywać kontradyktoryjności jako podstawowej zasady procesu cywilnego.

Instrumentem przyspieszającym postępowanie jest również możliwość ustalenia okoliczności w trybie art. $212 \S 1$ k.p.c., który stanowi, że sąd na rozprawie przez zadawanie pytań stronom dąży do tego, aby strony przytoczyły lub uzupełniły twierdzenia lub dowody na ich poparcie oraz udzieliły wyjaśnień koniecznych dla zgodnego z prawdą ustalenia podstawy faktycznej dochodzonych przez nie praw lub roszczeń. $W$ ten sam sposób sąd zmierza do wyjaśnienia istotnych okoliczności sprawy, które są sporne. $\mathrm{W}$ tym przypadku aktywność sądu ukierunkowana być może wyłącznie na pobudzanie inicjatywy dowodowej stron oraz pozyskiwanie od nich twierdzeń faktycznych, gdy są one niewystarczające do merytorycznej oceny zgłoszonego roszczenia lub obrony. Nie może ona jednak prowadzić do zastępowania stron i samodzielnego budowania przez sąd podstawy faktycznej żądania oraz przejmowania powinności stron związanych ze zbieraniem materiału dowodowego ${ }^{14}$. Przewidziane w tym przepisie wstępne wyjaśnienie stanowisk stron (informacyjne wysłuchanie) stanowi zatem bardzo ważny instrument umożliwiający, w ramach kierownictwa materialnego procesem, koncentrację materiału procesowego (art. 6 k.p.c.). Jego celem nie jest natomiast zaznajomienie sądu orzekającego ze wszystkimi informacjami i opiniami na temat rozpatrywanej sprawy, $z$ którymi strona zechce się podzielić ${ }^{15}$. Działania sądu na podstawie art. 212 k.p.c. nie mają zatem na celu zastąpić postępowania dowodowego jako zespołu czynności zmierzających do ustalenia faktów istotnych dla rozstrzygnięcia sprawy.

W tym ostatnim zakresie rolę mechanizmu przyspieszającego postępowanie pełni art. 217 k.p.c., w szczególności postanowienia $\$ 3$ tego przepisu, zgod-

\footnotetext{
12 Wyrok SN z dnia 5 lutego 2002 r., I PKN 846/00, Legalis.

13 Wyrok SA w Katowicach z dnia 20 stycznia 2017 r., V ACa 381/16, Legalis.

14 Wyrok SA w Warszawie z dnia 11 czerwca 2015 r., I ACa 1846/14, Legalis.

15 Wyrok SA w Łodzi z dnia 19 czerwca 2013 r., I ACa 49/13, Legalis.
} 
nie z którym sąd pomija twierdzenia i dowody, jeżeli są powoływane jedynie dla zwłoki lub okoliczności sporne zostały już dostatecznie wyjaśnione. Tym samym pominięcie przez sąd dowodu dopuszczalne jest jedynie wówczas, gdy okoliczności sporne zostały dostatecznie wyjaśnione zgodnie z twierdzeniami strony zgłaszającej ten dowód albo gdy chodzi o dowody nieprzydatne lub zgłoszone wyłącznie dla zwłoki ${ }^{16}$. Taka konstrukcja uprawnień sądu na gruncie postępowania dowodowego pozwala w pełni zrealizować dyrektywę wynikającą z art. 232 zd. 1 k.p.c., zgodnie z którym przedmiotem dowodu są fakty mające dla rozstrzygnięcia sprawy istotne znaczenie (z wyłączeniem faktów niewymagających dowodu). Zawężenie ram postępowania dowodowego do zakresu niezbędnego dla trafnego rozstrzygnięcia sprawy stanowi jeden z czynników przyspieszających tok postępowania przed sądem cywilnym.

\section{Sprawność postępowania cywilnego}

W języku ogólnym sprawność jest pojmowana jako „sprawna organizacja jakichś działań, czynności”" a „sprawny” to „taki, który świadczy o tym, że ktoś wykonuje dobrze powierzone mu czynności"18. Tym samym można przyjąć, że szybkość jest zaledwie jedną ze składowych pozwalających ocenić postępowanie jako sprawne względnie niesprawne. W doktrynie wskazuje się, że ocena ta musi być dokonywana w zakresie ogólnego zarządzania procesem zmierzającym do wydania orzeczenia w kontekście jego szybkości i unikania przewlekłości postępowania ${ }^{19}$. Jak podkreśla T. Wiśniewski, zazwyczaj należyta sprawność postępowania sądowego uzależniona jest $\mathrm{w}$ równym stopniu zarówno od właściwych rozwiązań proceduralnych, jak i prawidłowej praktyki związanej z ich realizacją. Jednym słowem, sprawność tę dostrzegać trzeba nie tylko w aspekcie określonych założeń ustawodawczych, lecz również w aspekcie konkretnej praktyki sądów, ich organizacji i struktury ustrojowej, a także z uwzględnieniem mentalności i nawyków kadry sędziowskiej ${ }^{20}$. Problem ten wykracza poza ramy ustawy procesowej i ukazuje znaczenie rozwiązań ustrojowych odnoszących się do organizacji sądownictwa powszechnego oraz wykonywania obowiązków przez poszczególnych sędziów. Tym samym badanie przez prezesa w ramach uprawnień

\footnotetext{
${ }^{16}$ Wyrok SA w Białymstoku z dnia 25 września 2015 r., I ACa 131/15, Legalis.

${ }^{17}$ http://sjp.pwn.pl/szukaj/sprawno\%C5\%9B\%C4\%87.html, 20.04.2017 r.

${ }^{18} \mathrm{http}: / /$ www.wsjp.pl/index.php?id_hasla=5043\&id_znaczenia=4974949\&l=22\&ind=0, 20.04.2017 r.

19 I. Hayduk-Hawrylak, Komentarz do art. 37b [w:] I. Hayduk-Hawrylak, B. Kołecki, A. Wleklińska Prawo o ustroju sądów powszechnych. Komentarz, Legalis 2017.

${ }^{20}$ T. Wiśniewski, Reguły koncentracji materiału procesowego (pozew, odpowiedź na pozew, pisma przygotowawcze) [w:] T. Wiśniewski, Postępowanie sądowe w sprawach cywilnych z udziałem przedsiębiorców, System Prawa Handlowego, Tom 7, Legalis 2013 i wskazana tam literatura.
} 
wynikających z nadzoru wewnętrznego sprawności postępowania sądowego (art. 37b $\$ 1$ pkt 1 Prawa o ustroju sądów powszechnych ${ }^{21}$ ) sprowadzałoby się do oceny właściwego zorganizowania pracy i funkcjonowania sędziego w ramach przydzielonych mu spraw. Dalej oznaczałoby to również badanie właściwego zorganizowania i wykorzystania czasu pracy na sesjach i w referacie w zakresie przydzielonych spraw, z zaznaczeniem, że ingerencja prezesa nie może dotyczyć samego procesu orzeczniczego. Granica w zakresie zarządzania procesem orzeczniczym a samym orzekaniem jest niewyraźna ${ }^{22}$. Nie można pozostawić poza oceną także samego sposobu prowadzenia przez sędziego rozpraw oraz kształtowania przez niego właściwego sposobu postrzegania wymiaru sprawiedliwości przez społeczeństwo ${ }^{23}$. W doktrynie pojawiają się również wątpliwości co do granic kształtowania sprawności postępowania w trybie poleceń służbowych w kontekście zasady niezawisłości sędziowskiej. Podstawowe pytanie odnosi się do tego, czy można np. w ramach polecenia służbowego nałożyć na sędziego obowiązek wyznaczenia określonej liczby sesji (posiedzeń) w miesiącu oraz liczby spraw na poszczególnych sesjach, sformułować oczekiwania co do zakończenia w ciągu miesiąca określonej liczby spraw albo zakończenia poszczególnych spraw $\mathrm{w}$ określonym terminie ${ }^{24}$. $\mathrm{Z}$ uwagi na zasygnalizowane, trudne określenie linii demarkacyjnej pomiędzy działaniami o charakterze czysto organizacyjnym a czynnościami, które mogą ingerować w niezawisłość sędziowską należy położyć nacisk na ostrożne korzystanie $\mathrm{z}$ uprawnień nadzorczych w oparciu o zoptymalizowane, maksymalnie precyzyjne kryteria ${ }^{25}$. Jednak warto zauważyć, że to nie narzędzia o charakterze administracyjnym oraz dyscyplinarnym stanowią zasadnicze narzędzie kształtowania sprawności postępowania cywilnego, bowiem ich działanie ma w głównej mierze charakter ex post, a więc wysoce niezadowalający, zwłaszcza z perspektywy postępowań, którym nie można przypisać cechy sprawności. Ważne jest wyposażenie przewodniczącego albo sąd w kompetencje pozwalające na uzyskanie sprawności postępowania na bieżąco, w jego trakcie. W celu realizacji tego postulatu Kodeks postępowania cywilnego wyposaża sędziego przewodniczącego w szereg uprawnień, ale też nakłada na niego określone obowiązki. Zagadnienie dotyczące roli, kompetencji i obowiązków przewodniczącego sądu pierwszej instancji nie cieszy się dotychczas szczególnym zainteresowaniem zarówno doktryny,

${ }^{21}$ Ustawa z 27 lipca 2001 r. - Prawo ustroju sądów powszechnych (t. jedn. Dz. U. z 2016 r., poz. 2062 ze zm.).

22 B. Godlewska-Michalak, Komentarz do art. 37b [w:] Prawo o ustroju sądów powszechnych. Komentarz, red. A. Górski, Lex 2013.

23 I. Hayduk-Hawrylak, op. cit., Legalis 2017.

24 K. Gonera, Podporządkowanie [w:] Pozycja ustrojowa sędziego, red. R. Piotrowski, Lex 2015.

25 A. Machnikowska, Sprawność postępowania sądowego w kontekście etosu sędziowskiego, Gdańskie Studia Prawnicze, Tom XXXIII, 2015, s. 237 i n. oraz wskazane tam orzecznictwo TK. 
jak i orzecznictwa Sądu Najwyższego ${ }^{26}$. Dlatego też niezbędne jest odniesienie się do instrumentów usprawniających postępowanie określonych w Kodeksie postępowania cywilnego w podstawowym zakresie, ze względu na ograniczone ramy opracowania.

Z perspektywy organów sądowych szczególne znaczenie mają kompetencje przewodniczącego pozwalające na należyte przygotowanie rozprawy. W myśl art. $208 \$ 1$ k.p.c. przewodniczący, stosownie do okoliczności, wyda przed rozprawą na podstawie pozwu i innych pism procesowych zarządzenia mające na celu przygotowanie rozprawy. Przewodniczący może w szczególności:

1. wezwać strony do stawienia się na rozprawę osobiście lub przez pełnomocnika,

2. zażądać na rozprawę od państwowej jednostki organizacyjnej lub jednostki organizacyjnej samorządu terytorialnego znajdujących się u nich dowodów, jeżeli strona sama dowodów tych otrzymać nie może,

3.wezwać na rozprawę wskazanych przez stronę świadków,

4. wezwać na rozprawę osoby powołane zgodnie przez strony na biegłych,

5. zarządzić przedstawienie dokumentów, przedmiotów oględzin, ksiąg, planów itd.

Przewodniczący może ponadto, w razie koniecznej potrzeby, zarządzić oględziny jeszcze przed rozprawą. Skuteczne wykorzystanie tych kompetencji przez przewodniczącego pozwala w znacznym stopniu usprawnić przebieg postępowania, a ponadto jest przejawem realizacji zasady koncentracji materiału procesowego i konstytucyjnej zasady rozpoznawania spraw bez nieuzasadnionej zwłoki ${ }^{27}$. Zadaniem przewodniczącego, wobec przykładowego charakteru wyliczonych zarządzeń, jest dostosowanie treści i zakresu swoich aktów decyzyjnych do okoliczności sprawy. Odnosi się to przede wszystkim do sytuacji, gdy strony złożyły już wnioski dowodowe w sprawie, wraz z wnioskami służącymi przygotowaniu rozprawy (zgodnie $z$ art. $187 \$ 2$ k.p.c.). Tym samym przepis ten nie nakłada na przewodniczącego żadnych konkretnych obowiązków. Co jednak istotniejsze, zaniechanie dokonania jakiejś konkretnej czynności przygotowującej rozprawę, nie może mieć żadnego znaczenia dla wyniku sprawy, albowiem strona procesowa może zgłaszać wszelkie środki dowodowe aż do zamknięcia rozprawy ${ }^{28}$. Przewodniczący powinien przewidzieć niezbędny czas trwania rozprawy i wydać takie zarządzenia, aby czynności procesowe mogły być na niej dokonane bez opóźnień i zbędnego pośpiechu niesprzyjającego zachowa-

${ }^{26}$ A. Zieliński, Rola, kompetencje i obowiązki przewodniczącego sądu pierwszej instancji, Aurea praxis aurea theoria. Księga pamiątkowa ku czci Profesora Tadeusza Erecińskiego, red. K. Weitz, J. Gudowski, t. 1 s. 829 i n.

${ }^{27}$ E. Wengerek, Koncentracja materiału procesowego w postępowaniu cywilnym, Warszawa 1958, s. 38.

${ }^{28}$ Wyrok SN z dnia 14 marca 2001 r., II UKN 269/00, Legalis. 
niu powagi sądu. Zarządzenia w zakresie przygotowania kolejnych posiedzeń wyznaczonych na rozprawę, jeżeli są wydawane na posiedzeniu niejawnym, należą do kompetencji przewodniczącego składu orzekającego (art. $47 \$ 3$ k.p.c.) ${ }^{29}$.

Warto podkreślić, że omawiane zarządzenia przewodniczącego wydawane w celu przygotowania rozprawy nie zastępują postanowienia dowodowego, które może zostać wydane wyłącznie przez sąd (art. 236 k.p.c.), co więcej nie przesądzają o treści tego postanowienia odnoszącej się do dopuszczenia środka dowodowego. Należy uznać, że podobne znaczenie mają proponowane zmiany Kodeksu postępowania cywilnego odnoszące się do możliwości przyjęcia przez sąd i strony harmonogramu postępowania dowodowego, obejmującego katalog dopuszczonych środków dowodowych i terminów ich przeprowadzenia na kolejnych posiedzeniach sądu. Tym przypadku również uporządkowania czynności w ramach postępowania dowodowego nie będzie stanowiło alternatywy dla postanowień dowodowych.

Z kolei strony mają obowiązek współdziałania w zakresie usprawnienia postępowania nie tylko poprzez stosowanie art. 3 k.p.c., ale również przez konstrukcje szczegółowe takie jak np. art. 162 k.p.c. Przepis ten stanowi, że strony mogą $\mathrm{w}$ toku posiedzenia, a jeżeli nie były obecne, na najbliższym posiedzeniu zwrócić uwagę sądu na uchybienia przepisom postępowania, wnosząc o wpisanie zastrzeżenia do protokołu. Stronie, która zastrzeżenia nie zgłosiła, nie przysługuje prawo powoływania się na takie uchybienia w dalszym toku postępowania, chyba że chodzi o przepisy postępowania, których naruszenie sąd powinien wziąć pod rozwagę z urzędu, albo że strona uprawdopodobni, iż nie zgłosiła zastrzeżeń bez swojej winy. Celem regulacji art. 162 k.p.c. jest zapobieganie nielojalności procesowej przez zobligowanie stron do zwracania na bieżąco uwagi sądu na wszelkie uchybienia procesowe w celu ich niezwłocznego wyeliminowania i niedopuszczenie do celowego tolerowania przez strony takich uchybień z zamiarem późniejszego wykorzystania ich w środkach odwoław$\mathrm{czych}^{30}$. Strona obecna na posiedzeniu może zatem zwrócić uwagę na uchybienia ustnie do protokołu posiedzenia bądź też w formie pisemnej - załącznika do protokołu (art. 161 k.p.c.), złożonego do końca posiedzenia, na którym była obecna. Natomiast strona nieobecna na posiedzeniu może zwrócić uwagę $\mathrm{w}$ formie pisemnej złożonej przed najbliższym posiedzeniem bądź też do końca najbliższego posiedzenia. W ten sposób usprawnia się postępowanie zarówno na etapie pierwszej instancji, jak i w drugiej instancji poprzez eliminację możliwości realizacji przez stronę strategii polegającej na ujawnianiu dostrzeżonych uchybień dopiero na późniejszym etapie postępowania ze szkodą dla sprawnego dążenia do uzyskania prawomocnego rozstrzygnięcia sprawy.

${ }^{29}$ J. Górowski, Komentarz do art. 208 k.p.c. [w:] Kodeks postępowania cywilnego. Tom I. Komentarz. Art. 1-366, red. A. Marciniak, K. Piasecki, Legalis 2016.

${ }^{30}$ Wyrok SN z dnia 4 października 2006 r., II CSK 229/06, Legalis. 
Również i w tym aspekcie należy przychylić się do stanowiska, że dążenie do sprawności postępowania może być często w opozycji do interesów stron i realizacji przez nie uprawnień procesowych ${ }^{31}$. Odnosi się to w szczególności do sytuacji, gdy strona postępowania liczy się z wysokim prawdopodobienstwem przegranej $\mathrm{w}$ procesie cywilnym i nie jest zainteresowana sprawnym prowadzeniem postępowania. W tym przypadku również można odnieść się do postanowień art. 103 k.p.c. jako narzędzia o charakterze represyjnym, przeciwdziałającego zachowaniom, które mogą mieć negatywny wpływ na sprawność postępowania. Takie podejście, przeciwstawiające dobro i autorytet wymiaru sprawiedliwości udzielającego ochrony prawnej podmiotom, której jej potrzebują, indywidualnym interesom stron, które nie zasługują na taką ochronę (np. w razie działań zmierzających do przewlekania postępowania przez dłużnika, wobec którego istnieją zasadne roszczenia), zasługuje z pewnością na akceptację. Judykatura $w$ tym zakresie przyjmuje bowiem jednoznaczne założenie, że równolegle $\mathrm{z}$ troską o osiąganie coraz wyższej jakości orzekania, należy doskonalić organizacyjną sprawność postępowania przed sądami, w szczególności przez pełne wykorzystywanie tych możliwości, jakie sądom stworzyło ustawodawstwo, a w konsekwencji doprowadzać do obniżenia - do granic niezbędności tzw. społecznych kosztów wymiaru sprawiedliwości ${ }^{32}$. Z pewnością postrzeganie postępowania jako niesprawnego przyczynia się nie tylko do spadku zaufania społeczeństwa do sądów powszechnych, ale również wywołuje negatywne konsekwencje związane z obniżeniem bezpieczeństwa prawnego i niekorzystaniem z obywateli z sądowych form ochrony prawnej w sytuacjach, gdy byłoby to aksjologicznie uzasadnione.

\section{Efektywność postępowania cywilnego}

Efektywność postępowania cywilnego należy postrzegać przede wszystkim w kategoriach trafnego rozstrzygnięcia sądu (względnie ugody zawartej między stronami), uzyskanego przy zaangażowaniu proporcjonalnych kosztów funkcjonowania organów wymiaru sprawiedliwości. Należy zaznaczyć, że „efektywny” to „dający dobre wyniki, wydajny”33, a „efektywność” oznacza „wydajność, pozytywny wynik, skuteczność” ${ }^{4}$. W literaturze podkreśla się, że efektywność postępowania cywilnego postrzega się jako czynnik determinu-

\footnotetext{
31 S. Rożek, Sprawność postępowania cywilnego - uwagi praktyczne i postulaty de lege ferenda, MOP 2006, Nr 21, s. 1150.

32 uchwała SN z dnia 15 lipca 1974 r., Kw Pr 2/74, Legalis.

33 http://sjp.pwn.pl/szukaj/efektywno\%C5\%9B\%C4\%87.html, 20.04.2017 r.

${ }^{34}$ http://sjp.pwn.pl/doroszewski/efektywnosc;5425211.html, 20.04.2017 r.
} 
jący realizację sprawiedliwości proceduralnej, a przez nią - prawa do sądu ${ }^{35}$. Efektywność postępowania należy do podstawowych założeń postępowania sądowego i stanowi konieczny warunek rzetelnego procesu. Zapewnienie efektywności postępowania wymaga pogodzenia podstawowego celu procesu, jakim jest wydanie sprawiedliwego orzeczenia, z postulatem rozpatrzenia sprawy jak najszybciej, a na pewno bez nieuzasadnionej zwłoki. Skuteczność ochrony sądowej w znacznym stopniu zależy od tego, jak szybko zostanie udzielona. Zapewnienie efektywnego możliwie najszybszego, a jednocześnie respektującego gwarancje procesowe postępowania należy do sądu, który umiejętnie stosując przepisy postępowania, powinien zapewnić mu właściwy przebieg $^{36}$. Jak podkreśla A. Łazarska, efektywność postępowania rozumiana jest jako cecha postępowania, która pozwala urzeczywistnić gwarancje prawa do sprawiedliwego rozpatrzenia sprawy bez nieuzasadnionej zwłoki. Obejmuje więc ona dwa aspekty: szybkość postępowania oraz możność rzeczywistego skorzystania $\mathrm{z}$ gwarancji ochrony sądowej ${ }^{37}$. W konsekwencji należy przyjąć, że mówiąc o efektywności postępowania cywilnego, należy mieć wzgląd przede wszystkim na rzetelność tego postępowania oraz trafność rozstrzygnięcia wydanego przez sąd. Efekt ten powinien być osiągnięty przede wszystkim przy zaangażowaniu jedynie koniecznych i uzasadnionych kosztów postępowania. Należy odróżnić konieczność utrzymywania przez Skarb Państwa systemu sądownictwa powszechnego, nawet jeśli koszt ten nie bilansuje się z wpływami z opłat sądowych i administracyjnych od sytuacji, w której dochodzi do nieuzasadnionego marnotrawienia zasobów dostępnych w ramach systemu wymiaru sprawiedliwości (np. poprzez zaangażowanie zbędnych środków finansowych i organizacyjnych w sprawy drobne i proste).

Zagadnienie efektywności może być także analizowane z punktu widzenia konstytucyjnej i ustrojowej roli sądów cywilnych, pozycji sędziego, adekwatności procedur sądowych, jak też formalnych gwarancji rzetelnego procesu sądowego ${ }^{38}$. W konsekwencji efektywność uzyskuje się zarówno przy użyciu instrumentów odnoszących się do szybkości i sprawności postępowania, jak i z uwzględnieniem konstrukcji dotyczących bezpośrednio celu postępowania, jakim jest trafne rozstrzygnięcie względnie ugodowe rozwiązanie sporu. To

${ }^{35}$ E. Gapska, Konkretyzacja stanowisk procesowych stron przed rozprawą i jej wpływ na efektywność postępowania, [w:] Postępowanie rozpoznawcze w przyszłym Kodeksie postępowania cywilnego, red. K. Markiewicz, A. Torbus, Legalis 2014 i wskazana tam literatura.

${ }^{36}$ Wyrok SA w Szczecinie z dnia 8 stycznia 2016 r., I ACa 339/15, LEX nr 2039739.

${ }^{37}$ A. Łazarska, Znaczenie efektywności [w:] A. Łazarska, Rzetelny proces cywilny, Warszawa, Lex 2012.

${ }^{38}$ A. Łazarska, Znaczenie efektywności [w:] A. Łazarska, Rzetelny proces cywilny, Warszawa, Lex 2012; T. Ereciński, K. Weitz, Efektywność ochrony prawnej udzielanej przez sądy w Polsce, PS 2005, nr 10, s. 3 i n.. 
ostatnie zakończenie postępowania jest preferowane na podstawie art. 10 k.p.c, zgodnie z którym w sprawach, w których zawarcie ugody jest dopuszczalne, sąd dąży w każdym stanie postępowania do ich ugodowego załatwienia, w szczególności przez nakłanianie stron do mediacji. Jednak do najczęściej występującego efektu postępowania w postaci rozstrzygnięcia sądowego odnoszą się postanowienia art. 227 k.p.c. w zakresie postępowania dowodowego oraz art. 224 k.p.c. wyznaczający moment, w którym można uznać, iż sprawa dojrzała do rozstrzygnięcia. Jak już wskazano, zgodnie z art. 227 k.p.c. przedmiotem dowodu są fakty mające dla rozstrzygnięcia sprawy istotne znaczenie. Przepis ten jest naruszony przez organ procesowy wtedy, gdy zostanie wykazane przez stronę, że sąd przeprowadził dowód bądź na okoliczności niemające istotnego znaczenia w sprawie i ta wadliwość postępowania dowodowego mogła mieć wpływ na wynik sprawy, bądź gdy odmówił przeprowadzenia dowodu na fakty mające istotne znaczenie $\mathrm{w}$ sprawie, wadliwie oceniając, iż nie mają one takiego charakteru $^{39}$. Natomiast art. 224 k.p.c. stanowi, że przewodniczący zamyka rozprawę po przeprowadzeniu dowodów i udzieleniu głosu stronom. Można zamknąć rozprawę również w wypadku, gdy ma być przeprowadzony jeszcze dowód przez sędziego wyznaczonego lub przez sąd wezwany albo gdy ma być przeprowadzony dowód $\mathrm{z}$ akt lub wyjaśnień organów administracji publicznej, a rozprawę co do tych dowodów sąd uzna za zbyteczną. Tym samym w obecnym stanie prawnym możliwość zamknięcia rozprawy nie jest uzależniona od wyrażenia przez sąd stanowiska co do dostatecznego wyjaśnienia sprawy, a jest to konsekwencją przyjętego modelu procesu cywilnego, w którym sąd nie ponosi odpowiedzialności za wynik postępowania dowodowego (art. $224 \S 1$ k.p.c. $)^{40}$. Tym samym przewodniczący prowadzi postępowanie jedynie w zakresie wyznaczonym niezbędną aktywnością stron, z zaangażowaniem adekwatnego do potrzeb czasu oraz zasobów ludzkich i rzeczowych.

Jedną z miar efektywności postępowania jest kwestia kosztów postępowania, w którym udziela się ochrony prawnej podmiotowi, który jej poszukuje. Postępowanie cywilne sądowe jest co do zasady postępowaniem odpłatnym. Oznacza to, że podmiot zamierzający uzyskać ochronę swoich praw w ramach postępowania sądowego jest zobowiązany do tymczasowego pokrycia kosztów postępowania, o ile przepis szczególny nie stanowi inaczej ${ }^{41}$. W tym zakresie podstawowe znaczenie ma także kryterium celowości i niezbędności kosztów poniesionych $\mathrm{w}$ toku postępowania przez strony. W tym względzie należy odnieść się do postanowień art. $109 \$ 2$ zd. 1 k.p.c., który stanowi, że orzekając

\footnotetext{
${ }^{39}$ Wyrok SA w Warszawie z dnia 17 czerwca 2015 r., VI ACa 1475/14, Legalis.

${ }^{40}$ Wyrok SA w Białymstoku z dnia 30 września 2015 r., I ACa 443/15, Legalis.

${ }^{41}$ M. Sorysz, Komentarz do art. 98 k.p.c. [w:] Kodeks postępowania cywilnego. Tom I. Komentarz. Art. 1-729

red. A. Góra-Błaszczykowska, Legalis 2015.
} 
o wysokości przyznanych stronie kosztów procesu, sąd bierze pod uwagę celowość poniesionych kosztów oraz niezbędność ich poniesienia $\mathrm{z}$ uwagi na charakter sprawy. Jak zaznacza A. Zieliński, celowość tych kosztów Kodeks postępowania cywilnego łączy z czynnością dochodzenia praw i celowej obrony. Nie może być ona utożsamiana $\mathrm{z}$ ich niezbędnością, która jest z kolei związana z kosztami ${ }^{42}$. To rozróżnienie jest o tyle istotne, że daną czynność niejednokrotnie można wykonywać na wiele sposobów, a każdy z nich generuje zróżnicowane koszty (np. porównanie kosztów dojazdu na salę rozpraw środkami komunikacji publicznej i taksówką).

W tej ocenie należy brać pod uwagę takie kryteria jak poziom skomplikowania sprawy, zakres przedstawionego materiału dowodowego oraz inne okoliczności wpływające na zakres nakładu pracy i zaangażowania składu orzekającego, stron i pełnomocników procesowych. Przykładem takiego podejścia do ustalania celowych i niezbędnych kosztów jest stanowisko wyrażone w judykaturze, zgodnie z którym jeżeli sprawa nie była skomplikowana - tak pod względem faktycznym, jak i prawnym, nie wymagała przeprowadzenia szczegółowego i czasochłonnego postępowania dowodowego, ani też ponadprzeciętnego zaangażowania w wyjaśnieniu istotnych okoliczności sprawy, a roszczenie każdego z powodów oparte zostało na takiej samej podstawie faktycznej i prawnej, przez co strona pozwana nie musiała ustosunkowywać się do każdego z nich osobno, wówczas zasadnym jest miarkowanie wynagrodzenia pełnomocnika pozwanego od każdego z tych współuczestników oddzielnie ${ }^{43}$. W odniesieniu do kosztów postępowania nie można podchodzić schematyczne, bowiem pozornie identyczne spory (co do rodzaju, co do wartości przedmiotu sporu, etc.) mogą obejmować okoliczności, które w znaczący sposób zmodyfikują pojmowanie określonych kosztów w kategoriach celowości i niezbędności. Przykładem tego może być naturalny przypadek braku zdolności postulacyjnej osoby głuchoniemej, który wygeneruje dodatkowe koszty udziału tłumacza języka migowego $\mathrm{w}$ postępowaniu.

Reasumując, proces, któremu możemy przypisać cechę efektywności powinien być szybki, prosty i tani ${ }^{44}$. Jednak model efektywnej ochrony prawnej powinien łączyć ideę sprawności postępowania oraz jego ekonomiki z zachowaniem nadrzędności celu w postaci trafnego rozstrzygnięcia ${ }^{45}$. Tym samym nie można efektywności postępowania traktować jako kategorii czysto ekonomicznej, w której aspekty kosztowe stanowią zasadnicze kryterium oceny. Wymiar sprawiedliwości w sprawach cywilnych jest odpłatny, ale nie może być nasta-

42 A. Zieliński, Komentarz do art. 98 k.p.c. [w:] Kodeks postępowania cywilnego. Komentarz, red. A. Zieliński, Legalis 2017.

${ }^{43}$ Wyrok SA w Białymstoku z dnia 7 października 2016 r., I ACa 380/16, Legalis.

${ }^{44}$ E. Waśkowski, Podręcznik procesu cywilnego, Wilno 1932, s.78 i n.

${ }^{45}$ K. Flaga-Gieruszyńska, Zastój procesu cywilnego, Szczecin 2011, s.52. 
wiony na zysk, a nawet na zbilansowanie swojej działalności, bowiem stanowić to będzie zaprzeczenie idei demokratycznego państwa prawnego.

\section{Wnioski}

Reasumując, omówione trzy kryteria jakości wymiaru sprawiedliwości: szybkość, sprawność oraz efektywność pojmowana jako skuteczność, odgrywają zróżnicowaną rolę w kształtowaniu standardów nowoczesnych usług publicznych świadczonych przez sądy powszechne. Jak podkreśla Trybunał Konstytucyjny, sprawność i efektywność postępowań prowadzonych przez organy władzy publicznej stanowią wartości chronione konstytucyjnie i są istotnym elementem porządku publicznego ${ }^{46}$. Wydaje się, że dopiero ich współistnienie z uwzględnieniem zasad postępowania cywilnego pozwala uznać, że mamy do czynienia z ich odpowiednią jakością, satysfakcjonującą obywateli. Co więcej, wielość czynników zewnętrznych (pozyskiwanie informacji z organów administracji publicznej, etc.) oraz wewnętrznych (zachowanie stron, świadków, biegłych, cechy osobowościowe sędziego, etc.) powoduje, że nie można stworzyć jednoznacznych parametrów, które pozwolą na zasadzie automatyzmu przyporządkować konkretnemu postępowaniu cech rzetelnego, efektywnego, a tym samym usługi publicznej należytej jakości. W konsekwencji można przyjąć, że ocena jakości tego rodzaju usług musi mieć charakter zindywidualizowany, bowiem musi brać pod uwagę również tak subiektywne kryteria jak poziom skomplikowania sprawy (ten element oceny może być zróżnicowany w zależności od poziomu wiedzy, kwalifikacji i percepcji składu orzekającego, stron i uczestników postępowania), znaczenie rozstrzygnięcia sprawy dla strony (np. znaczenie wyroku zasądzającego świadczenie alimentacyjne dla dziecka jest uzależnione od statusu majątkowego tego rodzica, z którym dziecko przebywa), czy aspekty emocjonalne związane z oczekiwaniem na zakończenie postępowania (obawa, utrata zaufania do realności rozstrzygnięcia wydanego w ramach długotrwałego postępowania i inne). To nie ułatwia weryfikacji jakości usług sądów powszechnych, które mają charakter orzeczniczy, w przeciwieństwie do tych, które mają bardziej jednowymiarowy charakter, np. informacyjny (działalność portali informacyjnych, BOI, biur podawczych, etc.). Stąd też wydaje się uzasadniona konieczność budowania wielowymiarowych narzędzi analitycznych, odnoszących się również do aspektów ekonomicznych i prakseologicznych, których istotą jest poszukiwanie tych obszarów działalności sądów powszechnych, w których można uzyskać wyższą jakość usług publicznych.

\footnotetext{
${ }^{46}$ Wyrok TK z dnia 20 kwietnia 2011 r., KP 7/09, OTK-A 2011, Nr 3, poz. 26.
} 


\section{Bibliografia}

\section{Akty prawne}

Ustawa z 17 listopada 1964 r. - Kodeks postępowania cywilnego (t. jedn. Dz.U. z 2016 r. poz. 1822 ze $z m$.

Ustawa z 27 lipca 2001 r. - Prawo ustroju sądów powszechnych (t. jedn. Dz. U. z 2016 r.

poz. 2062 ze zm.)

\section{Orzecznictwo}

Wyrok TK z dnia 20 kwietnia 2011 r., KP 7/09, OTK-A 2011, Nr 3, poz. 26.

Uchwała SN z dnia 15 lipca 1974 r., Kw Pr 2/74, Legalis.

Wyrok SN z dnia 19 maja 1976 r., IV PRN 9/76, Legalis.

Wyrok SN z dnia 22 września 1994 r., III CRN 30/94, Legalis.

Wyrok SN z dnia 14 marca 2001 r., II UKN 269/00, Legalis.

Wyrok SN z dnia 5 lutego 2002 r., I PKN 846/00, Legalis.

Wyrok SN z dnia 4 października 2006 r., II CSK 229/06, Legalis.

Wyrok SN z dnia 16 lipca 2009 r., I CSK 30/09, Legalis.

Postanowienie SN z dnia 16 czerwca 2016 r., V CSK 649/15, Legalis.

Wyrok SA w Łodzi z dnia 19 czerwca 2013 r., I ACa 49/13, Legalis.

Wyrok SA w Warszawie z dnia 11 czerwca 2015 r., I ACa 1846/14, Legalis.

Wyrok SA w Warszawie z dnia 17 czerwca 2015 r., VI ACa 1475/14, Legalis.

Wyrok SA w Białymstoku z dnia 25 września 2015 r., I ACa 131/15, Legalis.

Wyrok SA w Białymstoku z dnia 30 września 2015 r., I ACa 443/15, Legalis.

Wyrok SA w Szczecinie z dnia 8 stycznia 2016 r., I ACa 339/15, LEX nr 2039739.

Wyrok SA w Białymstoku z dnia 4 sierpnia 2016 r., I ACa 235/16, Legalis.

Wyrok SA w Białymstoku z dnia 7 października 2016 r., I ACa 380/16, Legalis.

Wyrok SA w Katowicach z dnia 20 stycznia 2017 r., V ACa 381/16, Legalis.

\section{Literatura}

Gapska E., Konkretyzacja stanowisk procesowych stron przed rozprawą i jej wpływ na efektywność postępowania, [w:] Postępowanie rozpoznawcze w przyszłym Kodeksie postępowania cywilnego, red. K. Markiewicz, A. Torbus, Legalis 2014.

Ereciński T., Weitz K., Efektywność ochrony prawnej udzielanej przez sądy w Polsce, PS 2005, nr 10. Flaga-Gieruszyńska K., Zastój procesu cywilnego, Szczecin 2011.

Hayduk-Hawrylak I., Kołecki B., Wleklińska A., Prawo o ustroju sądów powszechnych. Komentarz, Legalis 2017.

Kodeks postępowania cywilnego. Tom I. Komentarz. Art. 1-366, red. A. Marciniak, K. Piasecki, Legalis 2016.

Kodeks postępowania cywilnego. Tom I. Komentarz. Art. 1-729, red. A. Góra-Błaszczykowska, Legalis 2015.

Kodeks postępowania cywilnego. Komentarz, red. A. Zieliński, Legalis 2017.

Łazarska A., Rzetelny proces cywilny, Warszawa, Lex 2012. 
Machnikowska A., Sprawność postępowania sądowego w kontekście etosu sędziowskiego, Gdańskie Studia Prawnicze, Tom XXXIII, 2015.

Pozycja ustrojowa sędziego, red. R. Piotrowski, Lex 2015.

Prawo o ustroju sądów powszechnych. Komentarz, red. A. Górski, Lex 2013.

Rożek S., Sprawność postępowania cywilnego - uwagi praktyczne i postulaty de lege ferenda, MOP 2006, Nr 21, s. 1150.

Skuteczny wymiar sprawiedliwości - działania Ministerstwa Sprawiedliwości na 500 dni, Warszawa $2010 \mathrm{r}$.

Słownik języka polskiego online, sjp.pwn.pl

Waśkowski E., Podręcznik procesu cywilnego, Wilno 1932.

Wielki słownik języka polskiego online, www.wsjp.pl;

Wiśniewski T., Postępowanie sądowe w sprawach cywilnych z udziałem przedsiębiorców, System Prawa Handlowego, Tom 7, Legalis 2013.

Wengerek E., Koncentracja materiału procesowego w postępowaniu cywilnym, Warszawa 1958.

Zieliński A., Rola, kompetencje i obowiązki przewodniczącego sądu pierwszej instancji, Aurea praxis aurea theoria. Księga pamiątkowa ku czci Profesora Tadeusza Erecińskiego, red. K. Weitz, J. Gudowski, t. 1.

\section{Streszczenie}

Autorka przedstawiła trzy podstawowe pojęcia odnoszące się do prakseologicznych aspektów przebiegu postępowania cywilnego. Pierwszym pojęciem jest szybkość postępowania jako postulat przeciwdziałania przewlekłości postępowania. Drugim pojęciem jest sprawność rozumiana jako połączenie szybkości i odpowiedniego zorganizowania czynności w toku postępowania dążącego do celu, jakim jest trafne rozstrzygnięcie sądu. Trzecim pojęciem jest efektywność, co do której zasadnicze znaczenie ma optymalne osiągnięcie tego celu przy zaangażowaniu odpowiednich kosztów.

Słowa kluczowe: szybkość postępowania, sprawność postępowania, efektywność postępowania, przewlekłość postępowania.

\section{Speed, efficiency and effectiveness of civil proceedings - basic issues \\ Summary}

The Author presented three basic concepts related to the praxeological aspects of the course of civil proceedings. The first concept is the speed of the proceedings as a postulate counteracting the excessive length of the proceedings. The second concept is the efficiency understood as a combination of speed and proper organization of activities in the course of the proceedings aiming at a correct decision of the court. The third concept is the effectiveness, for which it is essential to achieve the goal optimally with the involvement of appropriate costs.

Keywords: speed of proceedings, efficiency of proceedings, effectiveness of proceedings, excessive length of proceedings. 